\title{
MICROBIOLOGICAL STUDY OF FRESH WHITE CHEESE (A SERBIAN CRAFT VARIETY)
}

\author{
D PEŠIĆ-MIKULEC ${ }^{1}$ - L. JOVANOVIĆ ${ }^{2}$ \\ e-mail:nivs@net.yu \\ ${ }^{1}$ Veterinary Research Institute \\ 11050 Belgrade, Borivoja Stevanovića 2., Serbia and Montenegro \\ ${ }^{2}$ BK University, Belgrade, Serbia and Montenegro \\ (Received $7^{\text {th }}$ March 2005, accepted $4^{\text {th }}$ August 2005)
}

\begin{abstract}
The levels of several microbial groups of aerobic mesophilic flora, aerobic psychrotrophic flora, lactic acid bacteria, Micrococcaceae, enterococci, Enterobacteriaceae, and molds and yeasts were investigated during the manufacture of fresh white cheese of a Serbian craft variety without the addition of starter culture. This variety of cheese is made in farmhouses from cow, sheep and goat's milk. White fresh cheese from mountain villages of Serbia has economical importance for this area. The study of the microbial characteristics of this cheese constitutes the first step towards the establishment of a starter culture which would allow the making of a product both more uniform and safer. The total microbial counts were high in these variety of cheeses. Almost all the microbial groups reached their maximum counts in curd. Lactic acid bacteria were the major microbial group, reaching count similar to the total aerobic mesophilic flora at all sampling points. Lactococcus lactis subsp. lactis dominated in milk $(62,5 \%)$ of the isolates obtained in the Man Rogosa Sharpe (MRS) agar at these sampling points, while the Lactobacillus casei subs.casei was the most predominant species $(83,5 \%$ of isolates obtained at these sampling points). The purpose of this study was to investigate the microflora of white cheeses with special emphasis on the autochthonous lactic acid bacteria involved in fermentation of this cheeses depending on the geographical location where the cheeses were manufactured.
\end{abstract}

Keywords. white soft cheese, farm manufactured, Serbian geographical location

\section{Introduction}

Fresh soft cheeses are made by using only traditional methods in the different geographical locations in Serbia. The traditional method of manufacture involves renneting curd formation, fermentation and preparation for markets. These cheeses are consumed in fresh form. Fresh soft cheeses are made by experienced cheese makers following the traditional methods. Its mass is white in color and compact, it has a slightly milky flavor. This cheese is made from raw milk, without species starters, which means that the ripening process is performed only by a natural flora of the milk. These factors together, without absence of any rigorous control of temperature and relative humidity during the ripening process, make the final product very variable. This lack of uniformity limits its acceptance and distribution on the home and foreign markets. There is no record that it has caused any health problems. Nevertheless, it is true that it is potentially unsafe and could cause problems in the future if its production conditions are not improved. Pasteurization of the milk intended for its production, a specific starter and controlled ripening conditions would allow the making of a uniform product of constant quality. These practices would also allow a safer production and would eliminate any potentional danger to the consumer. The aim of this study is to investigate the microbiological characteristics of this cheese and to isolate and identify the flora present during the ripening process. 


\section{Materials and methods}

Whole or skim raw milk was coagulated at $28-32^{\circ} \mathrm{C}$ by adding rennet, $1,5-2$ hours after the rennet was added, the curd was cut into almost equal parts $(4-5 \mathrm{~cm})$ and was left at room temperature, for approximately $15-18^{\circ} \mathrm{C}$. It was then placed in plastic or wood molds, of $12 \times 12 \mathrm{~cm}$ and $7 \mathrm{~cm}$ high with holes to allow the whey to drain. After 20 minutes the curd had been put into the molds and the whey allowed to drain again 40-60 minutes with pressure of $4 \mathrm{~kg}$, then dry salt was added to the surface. Ripening was performed in well aerated rooms at a temperature around $18^{\circ} \mathrm{C}$ for $8-10$ hours and relative humidity. Milk, curd and cheese were taken from different geographical location (Sopot, Mali Mokri Lug, Divčibare, Ivanjica, Obrenovac, Ub, Niš, Zaječar see Fig. 1.). Samples were transported to the laboratory under refrigeration (below $5^{\circ} \mathrm{C}$ ) and analyzed immediately. There were 10 samples from every location. The samples of cheeses were removed aseptically, $20 \mathrm{~g}$ of the samples were homogenized in $180 \mathrm{ml}$ of $2 \%(\mathrm{w} / \mathrm{v})$ sodium citrate solution and serial 10-fold dilutions were prepared from this homogenisate with $0,1 \%(\mathrm{w} / \mathrm{v})$ peptone water.

Figure 1. Geographical locations in Serbia where cheese samples were collected from

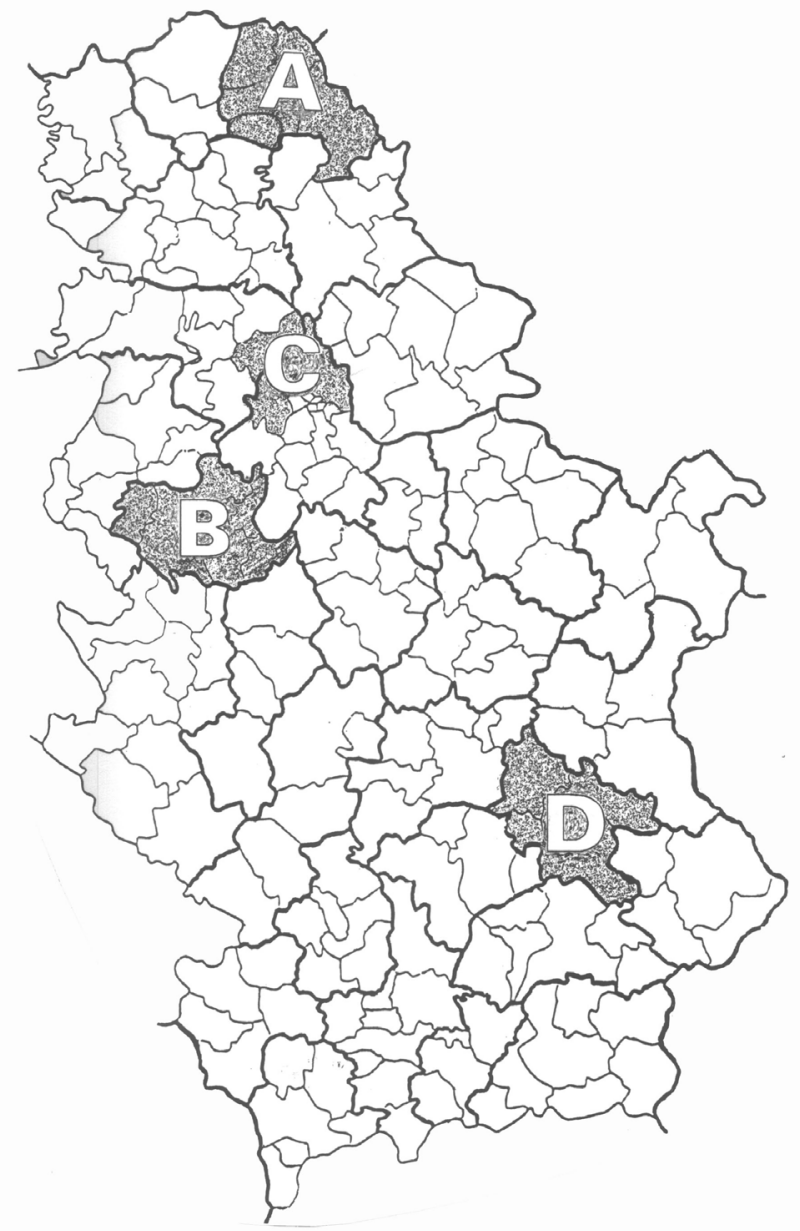

Aerobic mesophilic bacteria were enumerated in standard plate count agar after incubation at $30^{\circ} \mathrm{C}$ for $48 \mathrm{~h}$, aerobic psychrotrofic bacteria in standard plate count agar 
after incubation at $7^{\circ} \mathrm{C}$ for 10 days, lactic acid bacteria in the Man Rogosa Sharpe (MRS) M 17 (Merck) agar and Rogosa agar, after incubation at $30^{\circ} \mathrm{C}$ for 3 days, Micrococacceae in manitol salt agar (MSA) (Oxoid) incubated for $48 \mathrm{~h}$ at $30^{\circ} \mathrm{C}$, enterococci in kanamycin aeskulin azide agar incubated for $24 \mathrm{~h}$ at $37^{\circ} \mathrm{C}$, Enterobacteriaceae in violet red bile agar (VRBG) $(4-5 \mathrm{~cm})$ incubated for 18 to $24 \mathrm{~h}$ at $37^{\circ} \mathrm{C}$ and molds and yeasts in Sabourousd agar (Torlak) incubated for 5 days at $22^{\circ} \mathrm{C}$.

In standard plate count agar, MRS agar, KAA agar, VRBG agar and Sabouroud agar, $1 \mathrm{ml}$ of each dilution was inoculated in duplicate and mixed before solidification. Plates of MRS agar and VRBG agar were covered with a layer of the same medium before incubation. In mannitol salt agar $0,1 \mathrm{ml}$ volumes of each dilution were surface plated in duplicate. After incubation, plates with 30 to 300 colonies were counted.

At the end of the incubation period Lactobacilli were identified according to the methods and criteria of Sharpe [5,11], Leuconostoc were identified according to the methods and criteria of Garvie [5,11]. Streptococci were characterized according to the methods and criteria of Collins et al. [4] and Sharpe [11].

\section{Results and Discussion}

Table 1. shows the development of the different microbial group counts during the production of fresh white cheese of a Serbian craft variety. The milk used in the making the cheese used in this study shows high microbial counts (log total viable counts $7.22 / \mathrm{g}$ on average). The counts of the microbial groups investigated were in average two log units higher in curd than those recorded in milk. An increase in counts in curd is a normal process in cheese making which is, in part due to the physical retention of microorganisms in the coagulum and in part to microbial multiplication during coagulation and whey drainage. The lowest increase was observed in the molds and yeasts (only $1 \log$ unit) which seems to be the only microbial group that did not undergo any multiplication during coagulation and whey drainage. This circumstance may be due to the high coagulation temperature. The highest counts were reached for almost all the microbial groups in curd.

Table 1. Changes in log CFU/g of main microbial groups of fresh white cheese a Serbian craft variety during manufacturing and ripening (average values \pm standard deviation of four examples of cheeses)

\begin{tabular}{|l|c|c|c|}
\hline Microbial group & Milk & Curd & Fresh white cheese \\
\hline Aerobic mesophilic flora & $7.22 \pm 0,62$ & $9,41 \pm 0,28$ & $9,26 \pm 0,42$ \\
\hline Aerobic psychrotrophic flora & $6.53 \pm 1.12$ & $8.42 \pm 0.72$ & $8.06 \pm 0.58$ \\
\hline Lactic acid bacteria & $7.25 \pm 0,45$ & $9.42 \pm 0.26$ & $9.20 \pm 0,47$ \\
\hline Micrococaceae & $3.96 \pm 0.44$ & $5.31 \pm 0,16$ & $3.61 \pm 0.61$ \\
\hline Enterococci & $3.65 \pm 0.81$ & $5.62 \pm 1.49$ & $5.28 \pm 1.64$ \\
\hline Enterobacteriaceae & $4.14 \pm 1.71$ & $6.52 \pm 1.29$ & $4.20 \pm 1.93$ \\
\hline Molds and yeasts & $4.80 \pm 0,15$ & $5.80 \pm 0.55$ & $5.64 \pm 0.87$ \\
\hline
\end{tabular}

Lactic acid bacteria are by far the most significant microbial group in the production and ripening of this cheese, showing at all sampling points counts equal to or even higher than those of the total aerobic mesophilic flora. The predominance of lactic acid 
bacteria is also collaborated by the high correlation coefficient $(r=0,96)$ between their counts and those of total flora during the ripening process.

The aerobic psychrotrophic flora counts were always a log unit below those of aerobic mesophilic flora.

The Micrococcacceae counts dropped after the initial increase in the curd to values on the order of 103 colony forming units (CFU)/g and stayed at these levels throughout the ripening. The low Micrococcaceae levels found in this cheese suggest a low participation of this microbial group in the ripening of the cheese. It is important to point out that the Micrococcaceae family includes certain microorganisms which could cause potential danger to the health of the consumer. From this point of view, the low count of Micrococcaceae are a cause for relief. In Table 1. we represented the changes in log value of main microbial groups.

The enterococci do not undergo any noticeable reduction from the counts in curd (levels of about $105 \mathrm{CFU} / \mathrm{g}$ ).

The mold and yeast counts undergo an increase of log unit during coagulation and whey drainage and continue increasing to reach a maximum. We have not been able to find written information which would allow us to compare our data with those of other similar cheeses. It is also necessary to note that in our case, the samples were taken from the inside of the cheeses and yeasts and molds are most likely on the surface, showing a very low superficial microbial growth.

The high lactic acid bacteria count suggests that this flora type plays an important role in the ripening of this cheese. Table 2. shows the evolution of species isolated during the making and ripening of soft fresh cheeses. Lactococcus lactis subsp. lactis was by far the most prevalent species in milk $(62,5 \%$ of isolates) increasing its proportion in curd to $82,5 \%$ or even more. Lactococcus lactis subsp. diacetitylactis was isolated in only $5 \%$ of the curd, which is minimal. Only three species of lactobacilli were isolated: L.casei subsp casei, L.casei subsp alactosus and L.brevis, L.casei subsp.casei was by far the most frequent lactobacillus species isolated. L.casei subsp. casei definitely seems to play a fundamental role in the development of the organoleptic characteristic of fresh white cheese.

Table 2. Changes in species isolated from MRS agar during manufacturing and ripening of white soft cheeses row cow milk cheeses

\begin{tabular}{|l|c|c|c|c|}
\hline \multicolumn{1}{|c|}{ Species } & \multicolumn{2}{c|}{ Milk } & \multicolumn{2}{c|}{ White soft cheese } \\
\hline & $\begin{array}{c}\text { No.of } \\
\text { isolates }\end{array}$ & $\begin{array}{c}\text { Percentage } \\
\%\end{array}$ & $\begin{array}{c}\text { No. of } \\
\text { isolates }\end{array}$ & $\begin{array}{c}\text { Percentage } \\
\%\end{array}$ \\
\hline Lactobacillus casei subsp. casei & - & - & 1 & 2,5 \\
\hline Lactobacillus brevis & - & - & 1 & 2,5 \\
\hline Leuconostoc lactis & 6 & 15 & - & - \\
\hline Lactococcus lastis subsp. lactis & 25 & 62,5 & 33 & 82,5 \\
\hline Leuconostoc lactis subsp. diacetylactis & - & - & 2 & 5 \\
\hline Lactobacillus casei subsp. alactosus & - & - & 1 & 2,5 \\
\hline Streptococcus salivarius & - & - & 1 & 2,5 \\
\hline Total & 40 & 100 & 40 & 100 \\
\hline
\end{tabular}


The presence of heterofermentative lactobacili in soft fresh cheeses was very low and only six isolates were identified as Lactobacillus brevis. The isolation of L.brevis at the end of the ripening is not very typical. In other cheeses where this species or other betabacteria were described, $[1,10,8]$ they were mainly isolated during the first stage of ripening and then disappeared because of their sensitivity to the environmental conditions. This species has also been isolated in Swiss cheese, where it is considered responsible for the acidic flavor [2,3,7]. Leuconostoc lactis, the most acidifying leuconostoc species, was the most abundant species of the genus in the milk. The leuconostoc levels fell after the first month of ripening, which agrees with previous observations made by other authors [4,5,9]. Owing to the multiple technological properties of the leuconostocs and to the considerable levels which are found in white soft cheese, it is possible they have an additional role in the development of the organoleptic characteristics of this cheese.

Twenty strains of streptococci could not be exactly identified at a species level using only biochemical and cultural tests. The main functions which a starter should develop are: acid production, proteolysis, lipolysis, production of aroma, and inhibition of undesirable microorganisms.

\section{Conclusions}

The results of this work suggested that an adequate starter microorganism, selected from the most numerous microorganisms seems to be the main cause of the lipolytic and proteolytic phenomena and of the development of the flavor characteristics $[6,7,8]$. The presence of some leuconostoc species could improve the organoleptic characteristics of the final product. The cheese made from raw milk by traditional methods has the characteristics of different Serbian geographical locations.

\section{REFERENCES}

[1] Aran N. (1998): A microbial study of Kashar Cheese, Milchwissenchaft 53(10): 565-567.

[2] Axelson L.T. (1993): Lactic acid bacteria: Classification and physiology, In: Salminen A., von Wright A (eds.), Lactic acid bacteria, Marcel Deker, Inc., New York, USA, 1-63.

[3] Corroler D., Mangin I., Desmasures N., Gueguen M. (1998): An ecology study of lactococci isolated from raw milk in the Camembert cheese registered designation of origin area. - Appl. Environmental Microbiology 64: 4729- 4735.

[4] Collins E.B. (1962): Symposium on lactic starter cultures. Culture identity and selection, - J. Dairy Sci. 45: 1263-1266.

[5] De Man J.C., Rogosa M., Sharpe M.E. (1960): A medium for the cultivation of lactobacilli. - J. Appl. Bacteriol. 23: 130-135.

[6] IDF, Cheese and processes cheese product. Determination of chloride content. Potentiometric titration method. Standard 88 a, - Int. Dairy Fed., Brussels, Belgium.

[7] IOS, International Organization for Standardization, Cheese determination of fat content (van Guilk method) ISO 3433, 1975.

[8] Kandler O., Weiss N. (1986): Regular, nonsporing Gram-positive rods, In: Betler J.P. (ed), Bergeys manual of systematic bacteriology, Vol.2, William and Willkins, Baltimore, USA, pp. 1208-1260.

[9] Pešić-Mikulec Dragana, Rajić Nataša, Škrinjar Marija (2001): Bakteriocini bakterija mlečne kiseline. - Prehrambena industrija 12: No 1-2, 28-30.

[10]Mas M., Gonzales Crespo J. (1992): Lactic acid bacteria in Los Ibores cheeses. Alimentaria 92: 41-43. 
[11] Sharpe M.E. (1979): Identification of lactic acid bacteria, In: Skinner F.A., Lovelock D.W. (eds), Identification methods for microbiologists. - Academic Press, London UK, pp. 233-259

[12]Škrinjar Marija, Sedej Ivana, Pešić-Mikulec Dragana (2001): Effects of Lactobacillus acidophilus on the growth of Aspergillus ochraceus and ochratoxin A production in yoghurt. - Proceeding of 9th Int. Symp. Animal. Science Days, Radenci, Slovenia, 273276. 